\title{
Pemilihan Supplier Sodium Hiroxide Liquid Integrasi Dengan Metode AHP - Topsis
}

\author{
Muhamad Munir \\ Jurusan Teknik Industri, Universitas Muhammadiyah Malang \\ Jl. Raya Tlogomas 246 Malang 65144 Jawa Timur \\ Surel: muhamadmunir093@gmail.com
}

\begin{abstract}
PT. Eterindo Nusa Graha is a company engaged in basic chemical industry that produces synthetic resins and glycerine. One of the raw material for production of synthetic resins is DOP produced 45,000 tons/year. One adjuvant DOP is sodium hydroxide liquid. The raw material is supplied by several companies so that in choosing a major supplier to supply sodium hidroxide is important. Sodium hydroxide liquid supplied by Manunggal indah, Toya indo, and Surya Makmur. In reality the quality of raw materials are sometimes less suitable and delays in delivery have an impact on the production process. So that needs to be measured to determine the supplier's performance. Supplier selection is expected to suit the needs of PT. Eterindo Nusa Graha. This study aims to determine the criteria and sub-criteria supplier selection according to the needs of companies and provides the results of decisionmaking for the selection of the supplier company. The method used in this study is used AHP weighting of the criteria and sub-criteria and TOPSIS. The results of the research produced 6 criteria and 14 sub-criteria. Of AHP, the weight of the biggest criteria is Quality (0.38651) and Delivery (0.17208), while from TOPSIS method produces major supplier PT. Manunggal indah with positive ideal distance value 0.008558653 and negative ideal distance value 0.04522 .
\end{abstract}

Keywords: criteria, supplier selection, AHP, TOPSIS.

\begin{abstract}
Abstrak
PT. Eterindo Nusa Graha adalah perusahaan yang bergerak dalam bidang industri kimia dasar yang memproduksi resin sintetis \& glycerine. Salah satu bahan baku produksi resin sintetis adalah DOP yang diproduksi sebesar 45.000 ton/tahun. Salah satu bahan penolong DOP adalah sodium hidroxide liquid. Bahan baku ini dipasok oleh beberapa perusahaan sehingga dalam memilih supplier utama untuk memasok sodium hidroxide adalah hal yang penting. Sodium hidroxide liquide disupplai oleh PT Manunggal Indah, Toya Indah, dan Surya Makmur. Dalam realitakualitas bahan baku kadang kurang sesuai dan terjadi keterlambatan dalam pengiriman berdampak pada proses produksi. Sehingga perlu dilakukan pengukuran untuk mengetahui kinerja supplier. Pemilihan supplier diharapkan sesuai dengan kebutuhan dari PT. Eterindo Nusa Graha. Penelitian ini bertujuan untuk mengetahui kriteria dan subkriteria pemilihan supplier yang sesuai kebutuhanPT. Eterindo Nusa Graha dan memberikan hasil pengambilan keputusan untuk pemilihan supplier PT. Eterindo Nusa Graha. Metode yang digunakan dalam penelitian ini adalah AHP digunakan pembobotan terhadap kriteria dan subkriteria dan TOPSIS. Hasil dari penelitian menghasilkan 6 kriteria dan 14 subkriteria. Dari metode AHP, bobot kriteria terbesar adalah Quality (0,38651) dan Delivery (0,17208), sedangkan dari metode TOPSIS. menghasilkansupplier utama yaitu PT. Manunggal Indah dengan nilai jarak ideal positif 0,008558653dan nilai jarak ideal negatifo,04522.
\end{abstract}

Kata kunci: kriteria, pemilihan supplier, AHP, TOPSIS. 


\section{Pendahuluan}

PT. Eterindo Nusa Graha merupakan perusahaan manukfaktur yang bergerak di bidang produksi bahan kimia pelentur (plasticizer) dan resin sintetis (Water Based, Solvent Based) di Indonesia. Dalam industri ini, kualitas bahan baku yang dipesan harus $100 \%$ sama sesuai yang telah dipesan. Karena kesesuaian pemesanan menjadi tolok ukur agar produk yang dihasilkan sesuai kualifikasi standart dari konsumen. Untuk itu, perlu adanya perencanaan pembelian dengan mempertimbangkan faktorfaktor yang dapat mempengaruhi unsur produksi.

Sodium Hydroxide Liquid 48\% adalah salah satu bahan baku penolong untuk memproduksi dioctyl phthalate (DOP). PT Eterindo Nusa Graha adalah produsen terbesar DOP di Indonesia. Pemesanan bahan baku yang dilakukan secara periode satu bulan sekali dengan mempertimbangkan unsur kriteria dalam pembelian bahan baku. Kenyataan di lapangan bahwa supplier Sodium Hydroxide Liquid sering mengalami keterlambatan pengiriman dan kualitas dari bahan baku yang dikirim terkadang tidak sesuai dengan pesanan.Perusahaan melakukan pemilihan supplier dengan beberapa kriteria tapi pemilihan supplier tersebut masih belum tergolong akurat.Perusahaan ini berpatok pada kualitas, harga, dan pengiriman karena untuk memenuhi permintaan sesuai dengan pesanan dan juga untuk menaikan margin keuntungan perusahaan. Untuk itu permasalahan pemilihan supplier perlu dikaji ulang untuk memperoleh preferensisupplier terbaik untuk pemasok Sodium Hydroxide Liquid 48\% terkait permasalahanyang dihadapi perusahaan.

Tujuan dari penelitian dari tema pemilihan supplierini adalah mengidentifikasi kriteri-kriteria yang digunakan dalam pemilihan supplier bahan baku, memperoleh bobot kriteria yang digunakan dalam pemilihan supplier bahan bakuberdasarkan metode AHP, dan memilih supplier terbaik berdasarkan perhitunganpreferensi berdasarkan prioritas kriteria yang telah ditentukan dengan metode TOPSIS.

\section{Metode Penelitian}

Penelitian ini dibagi menjadi 5 tahap yaitu identifikasi awal, pengumpulan data, penolahan data, pembahasan serta kesimpulan dan saran.

\subsection{Tahap Identifikasi Awal}

Dalam proses melakukan penelitian, peneliti dapat memperoleh data dengan beberapa cara seperti wawancara dengan responden. Penelitian ini dilakukan dengan menggunakan metode wawancara kepada responden dan penyebaran kuisioner. Responden dalam penelitian ini adalah tunggal yakni staff purchasing yang memiliki pengetahuan yang cukup terhadap supplier dan performannya. Hal tersebut yang sangat berpengaruh terhadap pemilihan suplier terbaik dengan menggunakan metode AHP sebagai pembobotan kriteria dan TOPSIS sebagai metode pemilihan supplier.

\subsection{Tahap Pengolahan Data}

1. Menyusun Struktur Hierarki [1]: Penyusunan struktur hierarki diperoleh dari hasil wawancara kepada perusahaan mengenai kriteria dan supplier mengenai apa saja yang digunakan perusahaan dalam pemilihan supplier. Pemilihan supplier terbaik sangat penting dalam menyelesaikan kasus ini seperti yang terlihat pada gambar 4.2. Pemilihan supplier terbaik berada pada level 1, kemudian pada level 2 menjelaskan tentang kriteria spesifik seperti quality, cost, delivery, service, profile 
supplier, dandocument. Selanjutnya pada level 3 menjelaskan tentang sub kriteria dari kriteria spesifik yang mempunyai tolak ukur dalampenilaiannya seperti spesifikasi bahan baku, menejemen kualitas, harga produk,carapembayaran dan potongan harga dengan tolak ukur harga yang murah dalam rupiah. Keseluruhan kriteria dan sub kriteria dapat dibandingkan secara berpasangan karena menatanya secara logis sehingga tingkat tingkat itu saling berkaitan satu sama lain secara wajar.

2. Pengisian matriks perbandingan berpasangan oleh para expert Matriks diisi pada bagian atas garis diagonal dari kiri ke kanan, angka satu sampai dengan sembilan digunakan sebagai pembanding[2].

3. Menghitung matriks normalisasi matriks normalisasi yaitu membagi nilai dari setiap elemen didalam matriks berpasangan dengan nilai total dari setiap kolom. Perhitungan matriks normalisasi dapat dilakukan dengan menggunakan rumus pada persamaan 1 dan 2 [3].

$$
\begin{aligned}
& \mathrm{a}_{\mathrm{ij}}=\frac{1}{a_{j i}} ; \\
& \mathrm{wt}=\sum_{i=1}^{n} \frac{a i j}{n}
\end{aligned}
$$

4. Mengitung nilai eigen vector.

Nilai eigen vector yang dimaksud adalah nilai eigen value maksimum. Perhitungannilai eigen valuemaksimum dapat dilakukan dengan rumus persamaan 3,4 , dan 5 [3]

$$
\begin{aligned}
& (\mathrm{A})\left(\mathrm{w}^{\mathrm{T}}\right)=(\mathrm{v})\left(\mathrm{w}^{\mathrm{T}}\right) \\
& \left.\mathrm{wi}_{\mathrm{i}}=\frac{1}{n} \sum_{j} a_{i j}^{\prime}\right) \\
& \mathrm{t}=\frac{1}{n} \sum_{i=1}^{n}\left(\frac{\text { elemenke-ipada }(A)\left(w^{T}\right)}{\text { elemenke-ipadaw }}{ }^{T}\right)
\end{aligned}
$$

5. Melakukan pengujian/perhitungan konsistensi logis (CI).

Pengujian kosistensi ini adalah berfungsi untuk mengetahui konsistensi jawaban dari expert terhadap kuesioner yang diberikan. Perhitungan konsistensi logis dapat dilakukan dengan menggunakan rumus persamaan 9 dan 10 [3, 4].

$$
\begin{aligned}
& \mathrm{CI}=\frac{t-n}{b-1} \text { (pers.9) } \\
& \mathrm{CI}=\text { rasio penyimpangan (deviasi) konsistensi (consistency index) } \\
& \mathrm{t}=\text { Nilai eigen terbesar dari matriks berordo } \mathrm{n} \\
& \mathrm{n}=\text { ordo matriks } \\
& \mathrm{CR}=\frac{C I}{R I} \text { (pers.10) } \\
& \mathrm{CR}=\text { Rasio konsistensi } \\
& \mathrm{RI}=\text { Indeks Random }
\end{aligned}
$$$$
t=\text { Nilai eigen terbesar dari matriks berordo } n
$$

6. Menguji konsistensi Apabila rasio konsistensi $\leq 0.1$, maka hasil perhitungan data dapat dibenarkan. Hasil dari metode AHP digunakan sebagai input dalam metode TOPSIS.

7. Menyusun normalisasi matriks keputusan Hasil pembobotan metode AHP menjadi input metode TOPSIS. Bobot alternatif masing-masing subkriteria disejajarkan dalam satu kolom agar terlihat secara menyeluruh[5]. Perhitungan normalisasi matriks keputusan dapat dilakukan dengan menggunakan rumus persamaan 6 [3]

$$
r_{i j}=\frac{x_{i j}}{\sqrt{\sum_{i=1}^{m} x_{i j}^{2}}} \text {; dengan } \mathrm{i}=1,2 \ldots, \mathrm{m} ; \text { dan } \mathrm{j}=1,2, \ldots, \mathrm{n} . \ldots . .
$$

8. Memasukkan bobot ke dalam matriks keputusan Nilai secara keseluruhan alternatif dikalikan dengan nilai bobot masingmasing subkriteria. Perhitungan matriks ternormalisasi terbobot dapat dilakukan dengan menggunakan rumus persamaan $7[3]$. 
$\mathrm{y}_{\mathrm{ij}}=\mathrm{w}_{\mathrm{i}} \mathrm{r}_{\mathrm{ij}} ;$ dengan $\mathrm{i}=1,2, \ldots, \mathrm{m} ;$ dam $\mathrm{j}=1,2, \ldots, \mathrm{n}$

9. Menghitung solusi ideal positif dan solusi ideal negatif Perhitungan solusi ideal positif dan solusi ideal negatif dapat dilakukan dengan menggunakan rumus persamaan 8 dan 9 [3].

$$
\begin{aligned}
& \mathrm{A}^{+}=\left(\mathrm{y}_{1}{ }^{+}, \mathrm{y}_{2}{ }^{+}, \ldots, \mathrm{yn}_{\mathrm{n}}{ }^{+}\right) \\
& \mathrm{A}^{-}=\left(\mathrm{y}_{1}, \mathrm{y}_{2}^{-}, \ldots ., \mathrm{y}^{-}\right) \\
& \text {dengan } \\
& \mathrm{Y}_{\mathrm{j}}^{+}=\left\{\begin{array}{c}
\max y_{i j} ; \mathrm{jika} \mathrm{j} \text { adalah atribut keuntungan } \\
\min y_{i j} ; \mathrm{jika} \mathrm{j} \text { adalah atribut biaya }
\end{array}\right. \\
& \mathrm{Y}_{\mathrm{j}^{-}}=\left\{\begin{array}{c}
\min y_{i j} ; \mathrm{jika} \mathrm{j} \text { adalah atribut keutungan } \\
\max y_{i j} ; \mathrm{jika} \mathrm{j} \text { adalah atribut biaya }
\end{array}\right. \\
& \mathrm{j}=1,2, \ldots ., \mathrm{n}
\end{aligned}
$$

10. Menghitungjarak solusi ideal

Menghitung jarak solusi ideal antara alternatif $A_{i}$ dengan solusi ideal positif dirumuskan sebagai berikut [3]:

$$
\mathrm{D}_{\mathrm{i}}^{+}=\sqrt{\sum_{j=1}^{n}\left(y_{i}^{+}-y_{i j}\right)^{2}} ; \text { dengan } \mathrm{i}=1,2, \ldots, \mathrm{m} . \ldots
$$

Jarak antara alternatif $A_{i}$ dengan solusi ideal negatif dirumuskan sebagai berikut [3]:

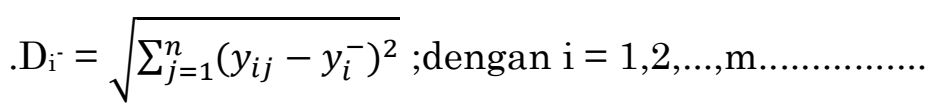

11. Menghitung nilai preferensi untuk setiap alternatif $\left(\mathrm{V}_{\mathrm{i}}\right)$ diberikan sebagai[3]:

$$
\mathrm{V}_{\mathrm{i}}=\frac{D_{i}^{-}}{D_{i}^{-}+D_{i}^{+}} ; \text {dengan } \mathrm{i}=1,2, \ldots, \mathrm{m} \text {. }
$$

12. Merangking supplier

Setelah melakukan perhitungan kedekatan relatif maka akan muncul hasil dari perankingan alternatif[6].

\subsection{Tahap Analisis Dan Pembahasan}

Setelah mendapatkan hasil dari pengolahan data untuk pembobotan dan peringkat kriteria, maka akan dihasilkan peringkat pada masing-masing supplier yang nantinya akan dijadikan sebagai salah satu bahan pertimbangan PT. Etrerindo Nusa Graha dalam hal pemesanan barang terhadap supplier.

\section{Hasil dan Pembahasan}

Penentuan Jumlah Kriteria dan Subkriteria pada PT. Eterindo Nusa Graha Berdasarkan dari kriteria yang berada dalam penelitian Dickson [7] dan penelitian Merry, dkk [8], kriteria pada pemilihan supplier berjumlah 22 kriteria. Sehingga dari 22 kriteria itu dilakukan survei terhadap PT. Eterindo Nusa Graha dengan menggunakan kuesioner untuk mengetahui jumlah kriteria yang sesuai dan digunakan oleh PT. Eterindo Nusa Graha. Kuesioner ini bersifat tertutup, sehingga pihak expert yang berada di PT. Eterindo Nusa Graha hanya mengisi kuisioner terkait kriteria dan subkriteria. Hasil survei melalui kuesioner tahap pertama disajikan pada tabel 1.

Penyusunan Masalah dalam Suatu Hierarki Tahapan pertama dalam metode AHP adalah penyusunan kriteria ke dalam hierarki. Hierarki tersebut terdiri dari tingkat pertama (tujuan/goal), tingkat kedua (kriteria dan subkriteria), tingkat ketiga (alternatif supplier)[9]. Hierarki dari kriteria dan subkriteria dapat dilihat dalam Gambar 1. 
Tabel 1 Kriteria Pemilihan Supplier

\begin{tabular}{ccc}
\hline No & Kriteria & Sub Kriteria \\
\hline 1 & Quality (Q) & $\begin{array}{c}\text { Spesisifikasi bahan baku (Q1) } \\
\text { Kadar larutan sulfat (Q2) }\end{array}$ \\
\hline 2 & Cost (C) & $\begin{array}{c}\text { Harga produk (C1) } \\
\text { Cara pembayaran (C2) } \\
\text { Diskon C3) }\end{array}$ \\
\hline 3 & Delivey (D) & $\begin{array}{c}\text { Ketepatan waktu pengiriman (S1) } \\
\text { Ketepatan jumlah pengiriman (S2) }\end{array}$ \\
\hline 4 & Service (P) & $\begin{array}{c}\text { Pelayanan setelah pemesanan (P1) } \\
\text { Komunikasi (P2) } \\
\text { Flexibilitas (P3) }\end{array}$ \\
\hline 5 & Profil supplier & $\begin{array}{c}\text { Performance history (PS1) } \\
\text { List konsumen (PS2) }\end{array}$ \\
\hline 6 & Document (Dt) & $\begin{array}{c}\text { Performance history (Dt1) } \\
\text { Purchase invoice (Dt2) }\end{array}$ \\
\hline
\end{tabular}

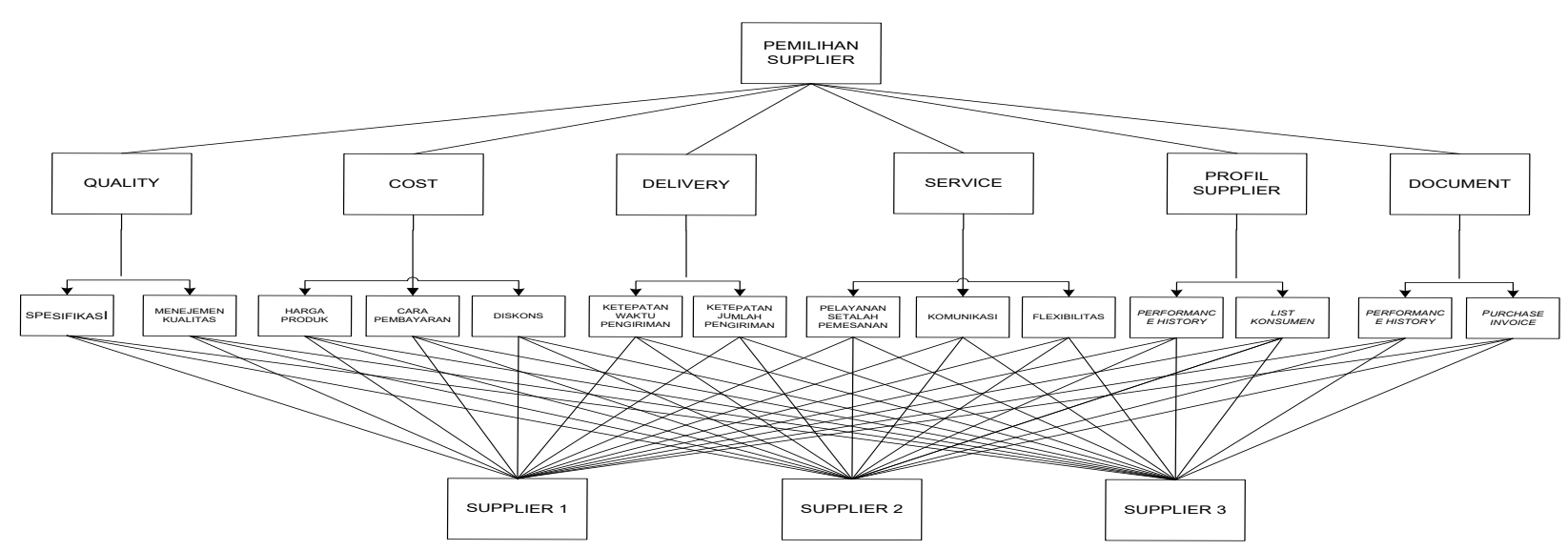

Gambar 1 Struktur Hierarki

Pengisian matriks perbandingan berpasangan diisi oleh Expert. Pengisian matriks perbandingan berpasangan dilakukan dua kali dalam bentuk kuesioner yang berbeda. Yang pertama adalah kuesioner matriks perbandingan berpasangan untuk kriteria dan yang kedua adalah kuesioner matriks perbandingan untuk subkriteria[4].

Membuat Matriks Perbandingan Berpasangan kemudian di masukkan ke dalam matriks perbandingan berpasangan[10]. Berikut contoh matriks perbandingan berpasangan untuk subkriteria pada kriteria quality pada Tabel 2

Tabel 2 Matriks Perbandingan Subkriteria pada Kriteria Quality

\begin{tabular}{lcc}
\hline \multicolumn{1}{c}{ Sub Kriteria } & $\begin{array}{c}\text { Spesifikasi Bahan } \\
\text { Baku }\end{array}$ & $\begin{array}{c}\text { Menejemen } \\
\text { Kualitas }\end{array}$ \\
\hline Spesifikasi Bahan Baku & 1 & 0,2 \\
\hline Menejemen Kualitas & 5 & 1 \\
\hline Jumlah & 6 & 1,2 \\
\hline
\end{tabular}


Menghitung matriks normalisasi matriks ternormalisasi di dapat dari nilai pada kolom dibagi dengan nilai total per kolom. Berikut contoh perhitungan untuk matriks normalisasi pada kriteria quality:

a. Menjumlahkan nilai pada setiap kolom (contoh pada subkriteria spesifikasi bahan baku) $\mathrm{Sij}=\sum$ Aijni=1 $\mathrm{Sij}=(1+5)=5$

b. Nilai setiap kolom dibagi dengan total nilai kolomnya $\mathrm{Vij}=\frac{A i j}{S i j}, \mathrm{Vij}=\frac{1}{6} \mathrm{Vij}=0,1667$

c. Merata-ratakan bobot yang sudah dinormalisasi dengan baris ke-i $\mathrm{Pi}=\frac{\sum \text { Qin }}{n}=$ $\frac{0,1667+0,1667}{2}=0,1667$

Tabel 3 Hasil Matriks Normalisasi untuk Subkriteria pada Kriteria Quality

\begin{tabular}{lccc}
\hline \multicolumn{1}{c}{ Sub Kriteria } & $\begin{array}{c}\text { Spesifikasi } \\
\text { Bahan Baku }\end{array}$ & $\begin{array}{c}\text { Menejemen } \\
\text { Kualitas }\end{array}$ & Bobot \\
\hline Spesifikasi bahan baku & 0,1667 & 0,1667 & 0,1667 \\
\hline Menejemen kualitas & 0,833 & 0,833 & 0,833 \\
\hline
\end{tabular}

Setelah melakukan matriks normalisasi, langkah selanjutnya adalah menghitung nilai bobot global pada subkriteria. Bobot global dapat dihasilkan dari perkalian bobot kriteria dengan bobot subkriteria. Berikut cara manual dari perhitungan bobot global porsentase spesifikasi bahan baku:

Bobot global = bobot quality* bobot subkriteria

$=0,1667 * 0,386515$

$=0,064419144$

Berikut hasil keseluruhan bobot global subkriteria pada tabel 4

Tabel 4 Bobot Global Subkriteria

\begin{tabular}{cll}
\hline \multirow{2}{*}{ Kriteria } & \multicolumn{1}{c}{ Sub Kriteria } & $\begin{array}{c}\text { Bobot } \\
\text { Global }\end{array}$ \\
\hline \multirow{2}{*}{ Quality } & Spesifikasi bahan baku & 0,064419144 \\
\cline { 2 - 3 } Cost & Menejemen kualitas & 0,322095722 \\
\cline { 2 - 3 } & Harga produk & 0,124818436 \\
\cline { 2 - 3 } & Cara pembayaran & 0,047785618 \\
\cline { 2 - 3 } Delivery & Diskon & 0,054828145 \\
\cline { 2 - 3 } & Ketepatan waktu pengiriman & 0,143402515 \\
\hline \multirow{2}{*}{ Service } & Ketepatan jumlah pengiriman & 0,028680503 \\
\cline { 2 - 3 } & Kelayanan setelah pemesanan & 0,015986655 \\
\cline { 2 - 3 } Profil & Flexibilitasi & 0,059649166 \\
\cline { 2 - 3 } Supplier & Performance history & 0,037936921 \\
\hline \multirow{2}{*}{ Document } & Performsumen & 0,010525903 \\
\cline { 2 - 3 } & Purchase invoice & 0,0279629517 \\
\hline
\end{tabular}

Dapat diketahui bahwa bobot kriteria secara berurutan dari bobot tertinggi adalah quality yaitu 0,386515 karena dari pihak perusahaan mengutamakan kualitas sebagai patokan yang utama dalam memilih sebuah supplier yang akan bekerja sama dengan perusahaan.Urutan kedua adalah kriteria Cost dengan bobot 0,227432 karena biaya memiliki aspek penting dalam memilih supplier. Dalam pemilihan supplier, cost berperan penting karena terkait keuangan yang dimiliki perusahaan sehingga pihak purchasing harus mempertimbangkan dengan tepat agar kebutuhan produksi perusahaan tetap dalam aliran lancar.Urutan ketiga adalah kriteria delivery yaitu 
0,172083 karena kriteria ini menjadi salah satu kriteria yang menjadi pertimbangan utama setelah kriteria quality dan cost.Ketepatan pengiriman merupakan hal penting dalam menjaga proses produksi dimana produksi berjalan kontinou. Dari ketiga kriteria yang menempati posisi teraratas dalam pembobotan dikarenakan kriteria quality, cost, dan delivery adalah kriteria yang saling berhubungan erat melihat perusahaan bergerak dalam produksi resin yang melakukan proses produksi secara kontinou.

Setelah melakukan perhitungan bobot global, maka langkah selanjutnya adalah menghitung nilai eigen value. Nilai eigen value dihasilkan dari perkalian dari matriks perbandingan berpasangan subkriteria dengan bobot parsial subkriteria. Berikut perhitungan vektor bobot sub kriteria quality:

$$
\left[\begin{array}{cc}
1 & 0,2 \\
5 & 1
\end{array}\right] *\left[\begin{array}{c}
0,1667 \\
0,833
\end{array}\right]=\begin{gathered}
(1 * 0,1667)+(0,2 * 0,883) \\
(5 * 0,1667)+(1 * 0,833)
\end{gathered}=\begin{aligned}
& 0,335 \\
& 1,665
\end{aligned}
$$

Setelah diketahui vektor bobot maka selanjutnya menghitung eigen value(t) dengan menggunakan persamaan 8. Langkah perhitunganya dapat dilihat seperti berikut:

$$
\begin{aligned}
& t=\frac{1}{2} \sum\left(\frac{0,335}{0,167}+\frac{1,665}{0,833}\right) \\
& t=2,004
\end{aligned}
$$

Setelah mengetahui perhitungan eigen value / $\lambda$ maks maka selanjutnya adalah melakukan perhitungan konsistensi logis (CI) dan mengujinya (CR). Apabila nilai $\mathrm{CR}<0,1$ maka data yang diambil sudahkonsisten. Berikut perhitungan CI dan CR subkriteria pada kriteria quality dengan menggunakan persamaan 6 dan 7

$$
\begin{aligned}
& \mathrm{CI}=\frac{t-n}{n-1}=\frac{2,004-2}{2-1}=\frac{0,004}{1}=0,004 \\
& \mathrm{CR}=\frac{C I}{R I}=\frac{0,004}{0}=0
\end{aligned}
$$

Setelah melakukan perhitungan konsistensi maka dilakukan pengujian terhadap konsistensi.Apabila nilai konsistensi $\mathrm{CR}<0,1$ maka penialain yang dilakukan oleh para expert konsisten. Berikut rekapitulasi hasil pengujian konsistensi pada tabel 5:

Tabel 5 Hasil Uji Konsistensi

\begin{tabular}{ccc}
\hline No & Kriteria & Hasil Uji Inkonsistensi \\
\hline 1 & Quality & 0 \\
\hline 2 & Cost & 0,01 \\
\hline 3 & Delivery & 0 \\
\hline 4 & Service & 0,023 \\
\hline 5 & Profil Supplier & 0 \\
\hline 6 & Document & 0 \\
\hline
\end{tabular}

Sebelum melakukan penyusunan normalisasi matriks keputusan, maka dilakukan pengukuran kinerja terhadap supplier dengan menggunakan kuesioner yang diisi oleh oleh expert. Hasil dari evaluasi tersebut kemudian dilakukan perhitungan berdasarkan kuesioner. Berikut contoh perhitungan dari matriks keputusan ternormalisasi dari sub kriteria quality pada subkriteriaspesifikasi bahan baku pada supplier PT.Manunggal Indah : 


$$
r_{i j=} \frac{x_{i j}}{\sqrt{\sum_{i=1}^{m} x_{i j}^{2}}} ; r_{11}=\frac{5}{\sqrt{5^{2}+5^{2}+5^{2}}}=0,5773503
$$

Memasukkan Bobot kedalam Matriks Keputusan

Setelah melakukan perhitungan matriks keputusan ternormalisasi maka langkah selanjutnya adalah menghitung matriks keputusan ternormalisasi terbobot. Matriks keputusan ternormalisasi terbobot dihasilkan dari perkalian matriks keputusan ternormalisasi subkriteria dengan bobot global dari subkriteria pada tabel 6. Berikut salah satu perhitunganmanual untuk matriks keputusan ternormalisasi terbobot subkriteria spesifikasi bahan baku:

$$
\mathrm{y}_{\mathrm{ij}}=\mathrm{w}_{\mathrm{i}} . \mathrm{r}_{\mathrm{ij}}, \mathrm{y}_{11}=\mathrm{w}_{1} . \mathrm{r}_{11}=0,064419144^{*} 0,5773503=0,003399
$$

Tabel 6 Rating Bobot Ternomalisasi

\begin{tabular}{cccc}
\hline $\begin{array}{c}\text { Sub } \\
\text { Kriteria }\end{array}$ & S1 & S2 & S3 \\
\hline Q1 & 0,003399 & 0,003399 & 0,003399 \\
\hline Q2 & 0,014712 & 0,011034 & 0,014712 \\
\hline C1 & 0,040404 & 0,040404 & 0,030303 \\
\hline C2 & 0,014296 & 0,014296 & 0,014296 \\
\hline C3 & 0,016403 & 0,016403 & 0,016403 \\
\hline D1 & 0,053699 & 0,042959 & 0,042959 \\
\hline D2 & 0,012735 & 0,012735 & 0,012735 \\
\hline S1 & 0,134542 & 0,134542 & 0,134542 \\
\hline S2 & 0,037496 & 0,029997 & 0,037496 \\
\hline S3 & 0,03488 & 0,03488 & 0,02616 \\
\hline PS1 & 0,025676 & 0,034235 & 0,025676 \\
\hline PS2 & 0,159623 & 0,159623 & 0,119717 \\
\hline DT1 & 0,129138 & 0,129138 & 0,129138 \\
\hline DT2 & 0,04723 & 0,04723 & 0,037784 \\
\hline
\end{tabular}

Matriks solusi ideal positif merupakan nilai maksimal dari matriks keputusan ternormalisasi terbobot, begitu juga dengan sebaliknya. Berikut salah satu perhitungan matriks solusi ideal positif dan solusi ideal negatif pada subkriteria porsentase bahan baku material yang mempunyai kualitas sesuai dengan spesifikasi dengan menggunakan persamaan rumus 8 dan 9 :

$$
\begin{aligned}
& \mathrm{A}^{+}=\left(\mathrm{y}_{1}^{+}, \mathrm{y}_{2}^{+}, \ldots, \mathrm{yn}^{+}\right) \\
& \mathrm{A}^{-}=\left(\mathrm{y}_{1}^{-}, \mathrm{y}_{2}^{-}, \ldots ., \mathrm{y}^{-}\right) \ldots
\end{aligned}
$$

Setelah melakukan perhitungan solusi ideal positif dan solusi ideal negatif, maka langkah selanjutnya adalah melakukan perhitungan separasi. Perhitungan jarak solusi menggunakan persamaan rumus 10 dan 11 yaitu menjumlahkan seluruh nilai kuadrat dari matriks ternormalisasi terbobot subkriteria dikurangi dengan nilai solusi ideal kemudian diakar. Berikut contoh perhitungan jarak solusi ideal:

$$
\begin{aligned}
& \mathrm{D}_{\mathrm{i}}^{+}=\sqrt{\sum_{j=1}^{n}\left(y_{i}^{+}-y_{i j}\right)^{2}}=0,008558653 \\
& \mathrm{D}_{\mathrm{i}}{ }^{-}=\sqrt{\sum_{j=1}^{n}\left(y_{i j}-y_{i}^{-}\right)^{2}}=0,04522
\end{aligned}
$$


Setelah melakukan perhitungan jarak solusi ideal, maka langkah selanjutnya adalah menghitung kedekatan relatif terhadap solusi ideal positif. Nilai kedekatan relatif terhadap solusi ideal positif didapatkan dari pembagian antara nilai separasi negatif dengan penjumlahan nilai separasi positif dan negatif. Berikut perhitungan manual dari nilai kedekatan relatif terhadap solusi ideal positif pada PT. PT Manunggal Indah dengan menggunakan persamaan 12:

$$
\begin{aligned}
& \mathrm{V}_{\mathrm{i}}=\frac{d_{1}^{-}}{d_{1}^{-}+d^{ \pm}} \\
& \mathrm{V}_{1}=\frac{0,04522}{0,04522+0,008558653} \\
& \mathrm{~V}_{1}=0,840855
\end{aligned}
$$

Setelah melakukan perhitungan dari nilai kedekatan relatif terhadap solusi ideal positif maka akan didapatkan ranking dari alternatif supplier. Hasil ranking dari alternatif disajikan pada tabel 7:

Tabel 7 Peringkat Supplier

\begin{tabular}{cc}
\hline Supplier & Nilai Preferensi \\
\hline S1 & 0,840855 \\
\hline S2 & 0,763677 \\
\hline S3 & 0,155801 \\
\hline
\end{tabular}

PT. Manunggal Indah (S1) memiliki jarak solusi ideal positif terkecil yaitu 0,008559 dan jarak solusi ideal negatif terbesar yaitu 0,04522, PT. Toya Indo memiliki jarak solusi ideal positif sebesar 0,013605 dan jarak solusi ideal negatif yaitu 0,043966, sedangkan PT. Surya Makmur mempunyai memiliki jarak solusi ideal positif sebesar 0,045259 dan jarak solusi ideal negatif yaitu 0,008353. Dari jarak solusi ideal dapat diperoleh PT. Manunggal Indah mempuyai nilai preferensi 0,840855, PT .Toya Indo Indah mempunyai nilai preferensi 0,763677, sedangkan PT. Surya Makmur mempunyai nilai preferensi 0,155801 .

Setelah dilakukan pemilihan supplier terbaik maka untuk mengetahui apakah supplier yang terpilih adalah yang terbaik dengan melakukan crosscheck dengan pihak purchasing perusahaan. Dengan perhitungan pembobotan yang telah dilakukan secara manual dengan menggunakan AHP bahwa hasilnya adalah quality menjadi kriteria yang memiliki bobot paling tinggi yakni 0,38651 disusul oleh cost dengan bobot 0,22743. Ini menunjukan hasil yang sama dengan dengan perusahaan tapi perhitungan yang dilakukan oleh perusahaan tidak menggunakan AHP. Tolok ukur yang digunakan perusahaan yang utama adalah quality, cost, dan delivery. Dalam penelitian ini peneliti menambahkan tiga kriteria yang mewakili perusahaan yakni service, profile supplier, dan document. Sehingga kriteria pemilihan supplier sodium hidroksida dapat lebih spesifik untuk mendapatkan supplier yang ideal.

\section{Simpulan}

Dalam proses pemilihan supplier terkait sodium hidroxide liquid 48\% kriteria yang digunakan berdasarkan kesepakatan peneliti dengan pihak purchasing, buku Pujawan Supply Chain Management edisi kedua, dan jurnal penelitian Merry, dkk (2014). Dengan kriteria yang diantaranya adalah quality, cost, delivery, service, profile supplier, dan document. Sedangkan sub kriteria yang digunakan adalah spesifikasi bahan baku, manajemen kualitas, harga bahan baku, cara pembayaran, diskon, ketepatan waktu pengiriman, ketepatan jumlah pengiriman, pelayanan setelah pemesanan, komunikasi, flexibilitas, performance history, list konsumen, performance 
history, dan purchase order. Jadi kriteria prioritas yang perlu diperhatikan adalah qualitydengan bobot 0,386515, cost dengan bobot 0,227432dan deliverydengan bobot 0,172083 . Sedangkan untuk sub kriteria prioritas yang perlu diperhatikan adalah manajemen kualitas, ketepatan waktu pengiriman, dan harga produk. Performansi keseluruhan dari calon supplier berdasarkan hasil perhitungan metode TOPSIS yaitu nilai preferensi terbesar menunjukkan hasil solusi alternatif terbaik pada penelitian ini, hasil dari masing masing nilai preferensi pada PT. Manunggal Indah mempuyai nilai preferensi 0,840855, PT .Toya Indo Indah mempunyai nilai preferensi 0,763677, sedangkan PT. Surya Makmur mempunyai nilai preferensi 0,155801. Dapat disimpulkan bahwa supplier yang terpilih berdasarkan nilai preferensi adalah PT. Manunggal Indah.

\section{Referensi}

[1] K. Mathiyazhagan, A. Diabat, A. Al-Refaie, and L. Xu, "Application of analytical hierarchy process to evaluate pressures to implement green supply chain management," Journal of Cleaner Production, vol. 107, pp. 229-236, 2015.

[2] T.-Y. Chen, "The inclusion-based TOPSIS method with interval-valued intuitionistic fuzzy sets for multiple criteria group decision making," Applied Soft Computing, vol. 26, pp. 57-73, 2015.

[3] S. Kusumadewi, S. Hartati, A. Harjoko, and R. Wardoyo, "Fuzzy Multi-Attribute Decision Making (Fuzzy MADM)," Yogyakarta: Graha Ilmu, 2006.

[4] A. Wicaksono, A. Rahman, and C. F. M. Tantrika, "Pemilihan Supplier Baja Hbeam Dengan Integrasi Metode Analytical Hierarchy Process Dan Technique for Order Preference by Similarity to Ideal Solution (Studi Kasus: CV. Dharma Kencana)," Jurnal Rekayasa dan Manajemen Sistem Industri, vol. 3, pp. p65-74, 2015.

[5] F. R. L. Junior, L. Osiro, and L. C. R. Carpinetti, "A comparison between Fuzzy AHP and Fuzzy TOPSIS methods to supplier selection," Applied Soft Computing, vol. 21, pp. 194-209, 2014.

[6] W. WAHYUDI, S. S. Komsiyah, N. I. Manik, and M. Kom, "Aplikasi Pengambilan Keputusan Dan Pemilihan Supplier Dengan Menggunakan Metode Ahp Topsis Dan Fuzzy Molp," BINUS, 2015.

[7] I. Pujawan and E. Mahendrawathi, "Supply Chain Manajemen, Surabaya, Indonesia," ed: Gunawidya, Surabaya, 2010.

[8] L. Merry, M. Ginting, and B. Marpaung, "Pemilihan Supplier Buah Dengan Pendekatan Metode Analytical Hierarchy Process (Ahp) Dan Topsis: Studi Kasus Pada Perusahaan Retail," Teknik dan Ilmu Komputer, vol. 3, 2014.

[9] N. Bahmani, R. G. Javalgi, and H. Blumburg, "An application of the analytical hierarchy process for a consumer choice problem," in Proceedings of the 1986 Academy of Marketing Science (AMS) Annual Conference, 2015, pp. 402-406.

[10] S. O. Viarani and H. R. Zadry, "Analisis Pemilihan Pemasok dengan Metode Analitycal Hierarchy Process di Proyek Indarung VI PT Semen Padang," Jurnal Optimasi Sistem Industri, vol. 14, pp. 55-70, 2015. 